\title{
Proximate composition and sensory assessment of beans pudding prepared using two different cooking methods
}

\author{
Mercy China $^{1 *}$, Nua J. Deedam ${ }^{1}$, Patricia Mbah² and Christabel Pepple ${ }^{2}$ \\ 1'Department of Food Science and Technology, Rivers State University, P.M.B.5080, Port Harcourt, \\ Rivers State, Nigeria. \\ 2Department of Home Science/Hospitality Management \& Tourism, Michael Okpara University of Agriculture, Umudike, \\ P.M.B.7267, Umuahia, Abia State, Nigeria. \\ *Corresponding author. Email: mercy4china@gmail.com
}

Copyright (C 2019 China et al. This article remains permanently open access under the terms of the Creative Commons Attribution License 4.0, which permits unrestricted use, distribution, and reproduction in any medium, provided the original work is properly cited.

Received 10th April, 2019; Accepted 29th April, 2019

\begin{abstract}
The effect of cooking methods on the proximate composition and sensory properties of beans pudding (moimoi) was investigated. Two cooking methods were used; dry-heat and steam cooking method. Results for proximate analysis showed that beans pudding prepared using dry-heat cooking method had moisture content of $69.10 \%$ while the steamed method recorded $71.89 \%$ moisture. Results show that there was a significant $(p<0.05)$ difference in the moisture, ash, fat, protein and crude fibre of the beans pudding samples. Dry heat cooking method recorded the highest in ash content $(1.90 \%)$, fat $(2.27 \%)$, protein $(5.56 \%)$ and carbohydrate content $(21.03 \%)$, while ash content for the steamed sample was $(1.68 \%)$, fat $(2.72 \%)$, protein $(4.81 \%)$ and carbohydrate $(18.79 \%)$. Sensory analysis showed that steamed sample was more preferred for all the parameters tasted than the dry heat sample with sensory scores for colour, taste, aroma, flavour, texture, sogginess and overall acceptability as 7.85, 8.40, 7.70, 7.95, 8.20, 7.10 and 8.60 respectively. However, there was no significant difference $(p>0.05)$ in the texture, sogginess, flavour and aroma of steamed and dry heat samples. Dry heat cooking method should be used for the preparation of beans pudding for nutritional retention, while steaming cooking method should be used to enhance the sensory properties of the food product.
\end{abstract}

Keywords: Beans pudding, dry heat, proximate, sensory evaluation, steaming.

\section{INTRODUCTION}

Cowpea (Vigna unguiculata (L.) Walp) is an annual herbaceous plant cultivated as a food source to human and livestock as well as cash crop to both subsistence and large scale farmers of most African countries (Odedeji and Oyeleke 2011). Presently, Nigeria is the largest producer of cowpea in the world; it is a protein that complements carbohydrate such as sorghum, corn and millet, thereby improving dietary provisions of households (Wada and Abubakar, 2013). Due to its tolerance for sandy soil and low rainfall, it is an important crop in the semi-arid regions across Africa and other continents. Okaka and Potter (1997) reported that it requires very few inputs since the root nodules are able to fix in atmospheric nitrogen, making it a valuable crop for poor farmers and also well- suited for intercropping. The whole plant is used as forage for animals and the cultivated cowpea also known as black-eye, pea, southern pea, yardlong bean, catjang and crowder pea as reported recently (United States Development of Agriculture and Natural Research Conservation Services, 2018). The most economically part of the crop remains the dry grain which is commonly boiled and eaten as beans porridge. Cowpea can be processed as flour, paste, deep fried cake (akara) or steam bean pudding (moi moi) and bean soup eaten as snacks in several Western and Central African countries (Boukar et al., 2011, Eke-Ejiofor and Kporna, 2019).

Akajiaku et al, (2014) and Sakpo and Osundahunsi (2016) reported that cowpea contain carbohydrates in the 
form of starch and small amount of non-polysaccharides and dietary fibre which helps to prevent constipation, bowel problems and piles so the richer the food in fibre the better for the consumers. International Institute of Tropical Agriculture (IITA, 2012) has shown that cowpea is a good source of plant based protein that has been identified as a meat alternative with a percentage of 21 to $25 \%$ protein by weight higher than other sources of vegetable protein which has a low glycemic index. This makes them an ideal food for the management of insulin resistance diabetics (Ogundele et al., 2015). Cowpea also contain potassium, a mineral that promotes healthy blood pressure levels, copper, phosphorous, magnesium, iron which makes them important for vegetarians and vegans who do not get an animal source of iron. It is a water-soluble vitamins like thiamin and folic acid and good sources of riboflavin and vitamin B6 (Eke- Ejiofor and Kporna, 2019; Olu et al., 2017). Chinma et al., (2008) reported that in countries such as Nigeria, and most of the Sub-Sahara countries, animal products representing high concentration and quality of protein are either too expensive or simply unaffordable, thus increasing the dependence on cereal grains, roots and tuber crops. However, the growth in the dietary share of cowpeas has been constrained by high preparation time, labour requirements, cooking methods and undesirable product characteristics. It also includes beany flavour, anti-nutritional factors and flatulence in man and other monogastric animals as well as post-harvest grain losses to insect pest (Olawuni et al., 2012; Akusu and kinnKabari 2012).

Cooking method influenced to a large extent the nutritional value and sensory parameters of food products (Alajaji and El-Adawy, 2006). Cowpea can be processed into paste by soaking, dehulling and milling which can be used for preparation of bean pudding popularly known as moi-moi and consumed in different forms in households. Henshaw et al. (2000) and Mixer et al. (2011) stated that it can be prepared by steaming the paste with several ingredients such as onion, fresh ground pepper, fish (usually combination of bell and chilli pepper scotch), bonnets made to slurry. It usually comes in a slanted pyramid variety of shapes when made with banana leaves or cylinder shape owing to the mold is poured into prior to cooking. The cylindrical shape comes from use of empty cans of tomatoes or cans of liquid milk used in the preparation of other dishes (Olu et al., 2017).

As stated by Kinton et al. (2005), there are basic methods of cooking used and they are divided into two general groups, namely dry and moist heat cooking methods. In dry heat cooking, the food being cooked does not come in direct contact with the heat applied. The methods are baking, steaming, grilling and roasting. In moist heat cooking, liquid is used to cook the food (such medium could be water, milk, oil, cream et cetera. These liquids are added to the food before heat is applied and they include, boiling, stewing, shallow frying, deep frying, barbequing and basting (Ihekoronye and Ngoddy 1985).
Food is any substance, liquid or solid which when taken will provide the body with the required nutrients for growth, repair of worn out tissues, energy, among others (Mixer et al. 2011). Over the years, it has been observed that different cooking methods have been used for some foods such as bean pudding. If the right cooking method is not used for the preparation of food it will affect the nutrients, flavour, digestibility, palatability, colour, appearance, taste, texture and the aim for eating will not be achieved. The problem statement therefore is whether the cooking method used in the preparation of moi-moi can have effect on the nutritional composition and sensory attributes. Bean pudding has been noted to be a good food for all ages, irrespective of health, this is because it digests easily when the right cooking method is used (Akusu and KiinKabari 2012). The study determined the effect of steamed and dry heat cooking methods on the proximate composition and sensory attributes of beans pudding. It is for this reason, that the study prepared beans pudding using dried heat and steam cooking method to assess their effects on the nutritional value and sensory attributes of the products.

\section{MATERIALS AND METHODS}

\section{Materials}

Cowpea seeds were purchased from Mile 3 Market in Port Harcourt Rivers State, Nigeria. Other laboratory materials and chemicals such as; measuring cylinder centrifuge tube, porcelain crucible, soxhlet extraction, desiccator, kjeldahl flask, beaker, whatman, filter paper, distilled water among others were collected from the analytical laboratory of Food Science and Technology, Rivers State University, Port Harcourt.

\section{Methods}

Cowpea paste was prepared as indicated in Figure1. Cowpea were cleaned and soaked in $100 \mathrm{ml}$ of tap water at $100^{\circ} \mathrm{C}$ for 2 hours, pre-soaked seeds were then dehulled, washed and addition of ingredients, milled and cowpea paste obtained was packaged in a plastic container until used (Figure 1). Cowpea paste was poured into a mixing bowl, vegetable oil, salt, seasoning and water were added and stirred thoroughly (Table 1). The paste was wrapped and steamed, allow to cool and serve as desired. For the dry heat cooking, the paste was poured into a cooking pan, stirred until cooked, then allow to cool and serve as desired.

\section{Proximate composition}

Moisture, protein, ether extract, crude fiber and ash contents of the beans pudding were determined by the 


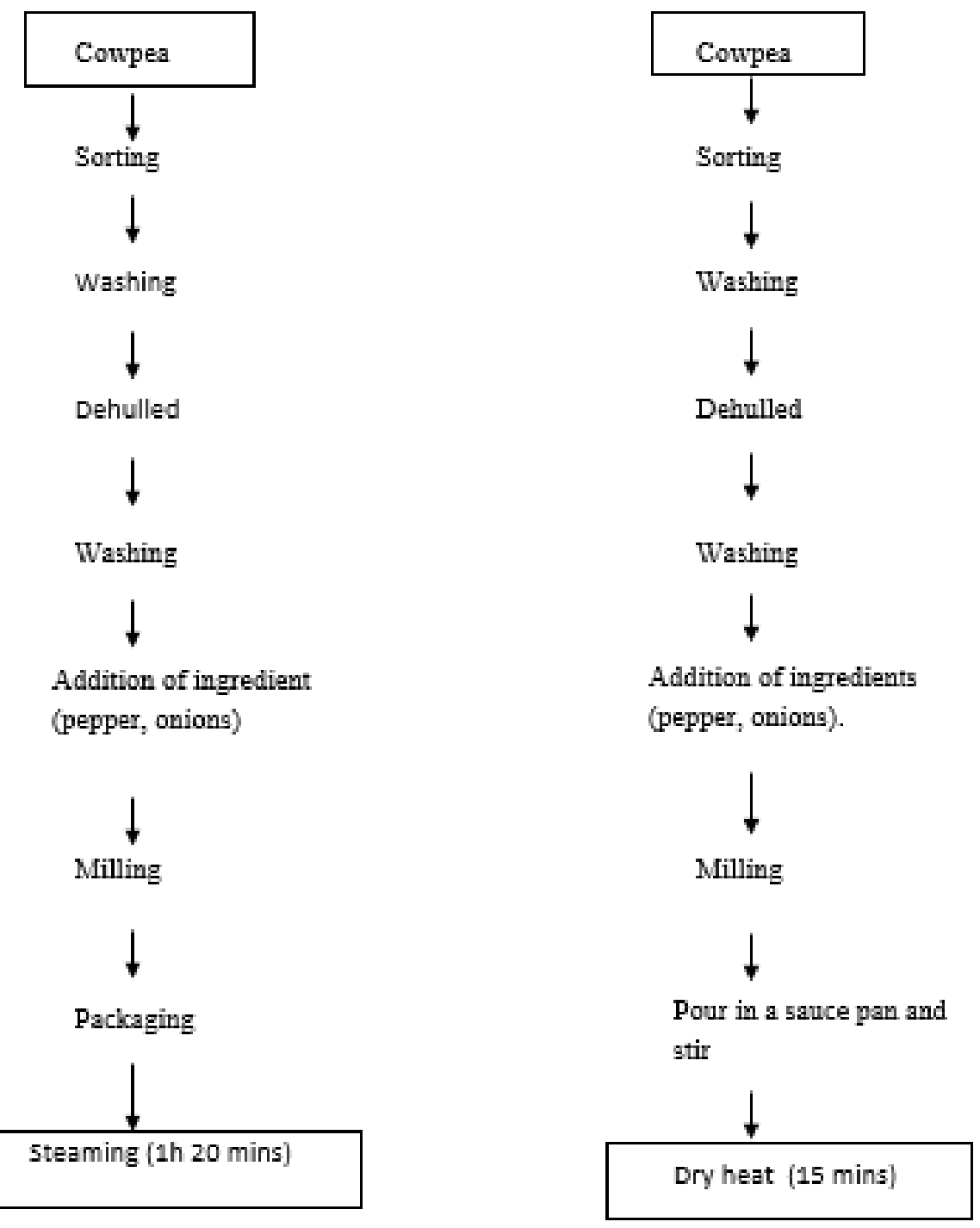

Figure 1. Cowpea paste preparation.

Table 1. Sample preparation of steam bean and dry heat pudding (moi-moi).

\begin{tabular}{ll}
\hline Ingredients & Weight \\
\hline Cowpea & $600 \mathrm{~g}$ \\
Onions (grind) & $25 \mathrm{~g}$ \\
Fresh pepper & $20 \mathrm{~g}$ \\
Vegetable oil & $140 \mathrm{ml}$ \\
Salt & $1.5 \mathrm{~g}$ \\
Seasoning & $1.5 \mathrm{~g}$ \\
Hot water (700 $\mathrm{C})$ & $150 \mathrm{ml}$ \\
T. daniellii (yoruba soft cane) & \\
\hline
\end{tabular}

(AOAC, 2006) methods. Carbohydrate content was done by difference.

\section{Moisture content}

The moisture content was determined by the (AOAC, 2006) method. The test material $(0.5 \pm 0.1 \mathrm{~g})$ was dried in the oven at $104 \pm 1 \mathrm{~g}$ to constant weight. Loss in weight was expressed as percentage moisture content.

$\%$ moisture content $=\frac{\text { weight loss }}{\text { Weight of sample }} \times 100$

\section{Crude protein}

Crude protein was determined in accordance with the standard of (AOAC, 2006) method. The test material $(0.5 \pm 0.1 \mathrm{~g})$ was digested with $10 \mathrm{ml}$ concentrated sulphuric acid in a Kjedal digested unit. The digest was diluted to 
$100 \mathrm{ml}$ with distilled water. An aliquot of the dilute digest $(10 \mathrm{ml})$ was distilled into $2 \%$ boric acid solution containing mixed indicator. Distillation was carried out by making steam to pass through a mixture of the digest and sodium hydroxide solution in a semi-micro distillation unit. Nitrogen liberated was thus passed into boric acid. The ammonium formed was titrated against normal sulphuric acid. The volume of acid used in the sample was used to calculate total nitrogen in the sample.

$\%$ Total Nitrogen $=\frac{(\text { Titre }- \text { blank }) \text { Normal }+1.4 \text { of acid }}{\text { Weight of sample }}$

Crude protein was calculated using factor of $6.25 \%$

Crude protein $=\%$ total nitrogen $\times$ total nitrogen $\times 6.25$

\section{Ash content}

Ash content was estimated by the (AOAC, 2006) method. Two gram $(2 \pm 0.1 \mathrm{~g})$ text sample was placed in a crucible and ignited in a muffle furnace at $55^{\circ} \mathrm{C}$. The difference in weight of crucible before and after weighing represented the weight of ash.

$\%$ ash content $=\frac{\text { weight of ash }}{\text { Weight of sample }} \times 100$

\section{Crude fibre}

Crude fibre was determined by the (AOAC, 2006) method. Deffated test sample $(0.5 \pm 0.1 \mathrm{~g})$ was digested with $100 \mathrm{ml}$ boiling sulphuric acid (1.25\%) to hydrolyze carbohydrate and protein material for 30 minutes. The acid removed by suction. The residue was washed with water. Further digestion was with $100 \mathrm{ml}$ boiling sodium hydroxide $(1.25 \%)$ to saponify fatty material. Sodium hydroxide solution was removed by suction. The residue was ignited in a furnace to burn off the fibre. The difference in weight before and after washing of the residue was expressed as percentage crude fibre.

$\%$ crude fibre $=\frac{\text { Loss in weight }}{\text { Weight of sample }} \times 100$

\section{Carbohydrate content}

The carbohydrate content was obtained by calculation difference.

\section{Sensory evaluation}

Quality characteristic including colour, sogginess, flavour, aroma, texture and overall acceptability were determine using the method by Iwe (2007). The panelist consisted of ten students from the Department of Food Science and Technology, Rivers State University Port Harcourt. Preference scores based on a 9-point hedonic scale was used.

\section{Statistical analysis}

The data obtained from the study were analyzed statistically using analysis of variance (ANOVA) and level of significance was set at $p \leq 0.05$.

\section{RESULTS AND DISCUSSION}

\section{Proximate composition}

Table 2 showed the proximate composition of steamed and dry heat transfer beans pudding. Moisture content ranged from 69.10 in dry treatment beans pudding to $71.89 \%$ in steamed bean pudding. The decrease in the moisture content of dry heated samples was due to increase in temperature and increase in surface due to continuous stirring. Increase in surface area relate to increase in moisture lost therefore, decrease in moisture content of the sample can be attributed to this factor. This result is in agreement with the observation by Eke-Ejiofor and Kporna (2019) and Akajiaku et al. (2014) who reported a decrease in the moisture content of cowpea. Snehal and Guha (2016) reported that dry heat cooking method significantly reduced moisture content of chickpea and soybean flour. The steaming method enhanced the sensory attributes of the product such as texture, colour, flavour et cetera while the dry heated sample decreased the sensory attributes of the product. However, there was nutrient retention in the dry heated samples compared to the steamed products. The moisture content of steamed bean obtained from this study were higher than the findings by Sefa-Dedeh et al. (2001) who observed a moisture content of $54.93 \%$ for steamed bean pudding The decrease in the moisture content of dry heated moimoi samples was influenced by the higher temperature. Heat treatment without any carrier (oil or water) has been showed to reduce the moisture content of cashew kernel seed than other thermal processing methods owing to the dry technique where the food sample are heat treated without immersing in a liquid as found by Olu et al. (2017). Emelike et al. (2018) and Akajiaku et al. (2014) showed that it is a known fact that dry heat dehydrates foods causing water loss while the increase in moisture of steamed sample was due to the moist heat employed in the process. Reduced moisture content of the dry heated sample ensures the inhibition of microbial growth, hence an important factor in food preservation. This may ensure high storage quality of the food product (Sakpo and Osundahunsi, 2016).

Ash content of the samples ranged from $1.68 \%$ in 
Table 2. Proximate composition of dry heat and steamed bean pudding.

\begin{tabular}{lcccccc}
\hline Cooking method & $\%$ Moisture & $\%$ Ash & \% Fat & \% Protein & $\%$ Crude fibre & $\%$ CHO \\
\hline Dry heat & $69.10 \pm 0.42^{\mathrm{b}}$ & $1.90 \pm 0.05^{\mathrm{a}}$ & $2.27 \pm 0.03^{\mathrm{b}}$ & $5.56 \pm 0.08^{\mathrm{a}}$ & $0.11 \pm 0.01^{\mathrm{a}}$ & $21.03 \pm 0.44^{\mathrm{a}}$ \\
Steaming & $71.89 \pm 0.30^{\mathrm{a}}$ & $1.68 \pm 0.06^{\mathrm{b}}$ & $2.72 \pm 0.07^{\mathrm{a}}$ & $4.81 \pm 0.05^{\mathrm{b}}$ & $0.12 \pm 0.03^{\mathrm{a}}$ & $18.79 \pm 0.27^{\mathrm{b}}$ \\
LSD & 1.53 & 0.08 & 0.32 & 0.30 & 0.18 & 0.50 \\
\hline
\end{tabular}

Values are mean \pm standard deviation of duplicate samples. Mean values bearing different superscript within the same column differ significantly $(p<0.05)$.

Table 3. Sensory evaluation of dry heat and steamed bean pudding.

\begin{tabular}{lccccccc}
\hline Cooking method & Colour & Taste & Aroma & Flavour & Texture & Sogginess & Overall Acceptability \\
\hline Dry heat & $6.40^{\mathrm{b}}$ & $7.30^{\mathrm{b}}$ & $6.80^{\mathrm{a}}$ & $7.30^{\mathrm{a}}$ & $6.85^{\mathrm{a}}$ & $5.75^{\mathrm{a}}$ & $7.30^{\mathrm{b}}$ \\
Steaming & $7.85^{\mathrm{a}}$ & $8.40^{\mathrm{a}}$ & $7.70^{\mathrm{a}}$ & $7.95^{\mathrm{a}}$ & $8.20^{\mathrm{a}}$ & $7.10^{\mathrm{a}}$ & $8.60^{\mathrm{a}}$ \\
LSD & 1.10 & 1.02 & 1.17 & 1.71 & 1.45 & 2.21 & 1.28 \\
\hline
\end{tabular}

Mean values bearing different superscript within the same column differ significantly $(p<0.05)$.

steamed sample to $1.90 \%$ in dry heat sample while the fat content of sample ranged from $2.27 \%$ in dry heat sample to $2.72 \%$ in steamed sample. Ash content may be associated with the amount of mineral present in a sample; hence the decreased crude ash recorded in this study for steamed sample apparently suggests a reduction in mineral content. In contrast, dry heated treatment further increased the ash content of the sample and this seemingly suggesting that dry heat may improve the mineral contents of bean pudding. This result agrees with the findings by Heong et al. (2011), an increase in the ash content of cowpea bean flour during dry heat roasting. The decrease in the ash content of the steamed sample may be attributed to leaching losses, especially during steaming process. Ash content of steamed bean pudding obtained from this study is in accordance with the findings by Ehimen et al. (2017) and Akusu and Kinn-Kabari (2012) who reported $1.17 \%$ and $1.39 \%$ respectively for moi-moi prepared using steamed cooking method. Ash content conveys an impression of the quality of metal ions bound to the raw material (Chinma et al., 2008).

The crude fat content was between $2.27 \%$ and $2.72 \%$ in dry heat and steamed sample respectively. Fat content usually plays a role in the shelf life stability of food products. The relatively low fat content of the dry heat justifies its shelf life stability (Mixer et al., 2011). This result is in agreement with the finding by Olawuni et al. (2012) who reported a decrease in the fat content of asparagus bean flour from 2.5 to $2.08 \%$ representing $20 \%$ reduction on roasting. The result obtained for steamed sample agrees with the findings by Ogundele et al. (2015) who reported $1.91 \%$ for steaming pudding. Value for protein content ranged from $4.81 \%$ in dry heat sample to $5.56 \%$ in steamed sample. The increase in percent protein content of dry heat sample might be attributed to the reduction in the moisture content by the dry-heat cooking method employed. The results were in agreement with the results obtained by El-Badrawy et al. (2016) and Osundahunsi and Aworh (2003) who reported increased protein content of roasted raw peanut.

Crude fibre ranged from $0.11 \%$ in dry heat sample to $0.12 \%$ in steamed sample. There was no significant $(p<0.05)$ difference in the crude fibre content of the samples. This is in agreement with result obtained by Enwere (2016) and could be due to the ingredients and formulation as showed by Ehimen et al. (2017) and Wada and Abubakar (2013). Value for carbohydrate content ranged from 21.03 to $18.79 \%$ for dry heat and steaming respectively. Dry heat sample recorded the highest value for carbohydrate. This result may be attributed to the cooking methods. The low value of carbohydrate recorded in the steamed sample was a result of leaching of some nutrients into the boiling water (Enwere, 2016; Olu et a.I, 2017).

\section{Sensory evaluation of dry heat and steamed bean pudding}

Table 3 showed the means sensory scores for steamed and dry heat treated bean pudding. Mean scores for colour ranged from 6.40 in heat treated sample to 7.85 in steamed sample. The result showed that wrap and steamed sample was most preferred due to the cooking method applied. It was as a result of the product not in direct contact with boiling water. This result was in line with the observation by Akusu and Kinn-Kabari (2012), who pointed out that steaming method of cooking bean pudding enhances the colour of the product. Value for taste ranged from 7.39 in dry heat treated sample to 8.40 in the steamed sample. Cooking is vital for beans pudding due to the presence of compounds that can adversely affect nutritional value. It also increasing protein and desirable sensory attributes of the products (Osundahunsi and Aworh, 2003). Rating scores for aroma ranged from 6.80 in dry heat treated sample to 7.70 in steamed sample. 
Sensory score for flavor ranged from 7.30 in heat treated sample to 9.95 in steamed sample. This was as a result of their similarities in the ingredients impacted on the aroma and flavour of the product (Akajiaku et al., 2014). Means scores for texture ranged from 6.85 in dry heat treated sample to 8.20 in steamed sample. This was influence by the cooking used. Value for sogginess ranged from 5.75 in heat treated sample to 7.10 in steamed sample while mean scores for general acceptability of the samples ranged from 7.30 in dry heat treated sample to 8.60 in steamed sample. This could be as a result of the different cooking methods used for the products. However, the steamed sample was generally accepted.

\section{Conclusions}

The study revealed that dry heat treated cooking method improved the nutritional content of the product than steamed product. However steaming method of cooking enhanced the sensory attributes of the product compared to dry heat treated product. For nutrient retention, dry heat treated cooking method was most preferable while for sensory preference, steaming cooking method was desirable. The study therefore recommended that dry treated cooking method should be used to retain and enhance the nutritive value of beans pudding and steamed cooking should be used for improvement of sensory attributes of beans pudding.

\section{CONFLICT OF INTEREST}

The authors declare that they have no conflict of interest.

\section{REFERENCES}

Akajiaku, L. O., Nwosu, J. N., Odimegwu, E. N. Alagboso, S. O., \& Uzoechi, J. C. (2014). Influence of sprouted pigean pea (Cajan cajan) flour inclusion on sensory quality of moi-moi. The International Journal and Technoledge, 2(12), 122-129.

Akusu, M. O., \& Kiin-Kabari, D. B. (2012). Protein quality and sensory evaluation of moi-moi prepared from cowpea/maize flour blends. African Journal of Food Science, 6(3), 47-51.

Alajaji, S. A., \& El-Adawy, T. A. (2006). Nutritional composition of chickpea (Cicer arietinum L.) as affected by microwave cooking and other traditional cooking methods. Journal of Food Composition and Analysis, 19(8), 806-812.

AOAC (2006). Official Methods of Analysis of Association of the Association of Official Analytical Chemists (20th Edn.). Washington, D.C., USA.

Boukar, O., Massawe, F., Muranaka, S., Franco, J., MaziyaDixon, B., Singh, B., \& Fatokun, C. (2011). Evaluation of cowpea germplasm lines for protein and mineral concentrations in grains. Plant Genetic Resources, 9(4), 515522

Chinma, C. E., Alemede, I. C., \& Emelife, I. G. (2008). Physiochemical and functional properties of some Nigerian cowpea varieties. Pakistan Journal of Nutrition, 7(1), 186-190.
Ehimen, R. O., Abiodun, A. A., Michael, A. L., Olajide, P. S. Adeniyi, A. T., Raphael, O. L., Simeon, O. A., Tolulope, O. O., \& Avoonnde, F. (2017). Nutrient composition functional and pasting properties of unripe cooking banana, pigeon pea and sweet potato flour blends. Journal of Food Science and Nutrition, 5(3), 750-762.

Eke-Ejiofor, J., \& Kporna, J. D. (2019). Nutrient and sensory evaluation of cowpea-Acha flour blends in pudding production. Food Science and Nutrition Technology, 4(1), 1-11.

El-Badrawy, E. E. Y., El-Zainy, A. M., Shalaby, A. O., \& El-Sayed, N. Y. (2016). Effect of microwave roasting on chemical composition of peanut seeds and comparing it with the ordinary roasting process. Proceeding of Annual Conference Credit \& Accreditation, Faculty of Specific Education, Mansoura University, Egypt.

Emelike, N. J. T., Akusu, M. O., \& Ujong, A. E. (2018). Antioxidant and physicochemical properties of oils extracted from cashew (Anacardium occidentale L.) Kernels. International Journal of Food Science and Nutrition, 26,122-128.

Enwere, N. J. (2016). Effect of tempering and drying on the functional properties and performance of cowpea flour during Akara and moi-moi preparations. M.Sc. Thesis, Department of Food Science and Technology. University of Nigeria, Nsukka.

Henshaw, F. O., Uzochukwu, S. V. A., \& Bello, I. Y. (2000). Sensory properties of akara (fried cowpea paste) prepared from paste stored at low storage temperatures. International Journal of Food properties, 3(2), 295-304.

Heong, C. S., Bhupinder, K., Huda, N., Karim, A. A., \& Fazilan, A. (2011). Effect of fermentation on the composition of Centella asiatica teas. American Journal of Food Technology, 6(7), 581-593.

Ihekoronye, A. L., \& Ngoddy, P. O. (1985). Integrated Food Science and Technology for the Tropics. Macmillian Publishers Ltd. London, and Basinstoke, Pp. 180-245.

International Institute of Tropical Agriculture (IITA) (2012). Agency Report, Cowpea Driving Silent Economic Revolution in Nigeria.

Iwe, M. O. (2007). Current trends in sensory evaluation of foods. Rejoint Communication Services Ltd. Enugu, Nigeria, (1st Edn.). p. 138.

Kinton, R., Ceserani, V., \& Foskets, D. (2005). Theory of Catering. 9th Edition. ELST Publishing. Pp. 388-389.

Mixer, D. A., Porter, M., Sonnier, B. \& Drummonds, K.E. (2011). Food preparation for the professionals. 3rd Edition. John Wiley Publishers and Sons. Pp. 145-146.

Odedeji, J. O., \& Oyeleke, W. A. (2011). Proximate, physiocochemical and organoleptical properties of whole and dehulled cowpea seed flour (Vigna unguiculata). Paskitan Journal of Nutrition, 10(12) 1175-1178.

Ogundele, G. F., Ojubanire, B. A., \& Bamidele, O. P. (2015). Proximate composition and organoleptic evaluation of cowpea (VignauguCulata) and soybean (Glycine Max) Blends for the Production of moi-moi and Ekuru (Steamed Cowpea Paste). Journal of Experimental Biology and Agricultural Sciences, $3(2), 207-212$.

Okaka, J. C., \& Potter, N. N. (1979). Sensory, nutritional and storage properties of cowpea powders processed to reduce beany flavor. Journal of Food Science, 44(5), 1539-1542.

Olawuni, I. A., Ojukwu, M., \& Eboh, B. (2012). Comparative study on the physio-chemical properties of pigeon pea (Cajan cajan) flour and protein isolate. International Journal of Agricultural and Food Science, 2(4), 121-126.

Olu, M., Rotimi, A., \& Emmanuel, A. A. (2017). Development of spiced instant moi-moi produced from pre-cooked cowpea 
using maize starch as binder. International Journal of Food Science and Nutrition Engineering, 7(4), 75-90.

Osundahunsi, O. F., \& Aworh, O. C. (2003). Nutritional evaluation, with emphasis on protein quality, of maize-based complementary foods enriched with soya bean and cowpea tempe. International Journal of Food Science and Technology, 38(7), 809-813.

Sakpo, I. O., \& Osundahunsi, O. F. (2016). Effect of cowpea enrichment on the phyco-chemical, mineral and microbiological properties of maize: cowpea flour blends. Research Journal of Food Science and Nutrition, 1(2), 35-41.

Sefa-Dedeh, S., Kluvitse, Y., \& Afoakwa, E. O. (2001). Influence of fermentation and cowpea steaming on some quality characteristics of maize-cowpea blends. African Journal of Science and Technology, 2(2),71-80.
Snehal, D., \& Guha, M. (2016). Nutritional, physico-chemical and functional properties of ready to use chickpea and soybean flour. International Journal of Food and Nutritional Sciences, 4(5), $72-78$.

United States Development of Agricultural \& National Research Conservation Service (USDANRCS) (2018). The planet database version 3.5. National Plant Data Centre, Baton Rouge, LA 70874- $4490 \quad$ USA, 2012. http://www.plant.usda.gov. Retrieved February 2nd.2019.

Wada, B. Y., \& Abubakar, B. Y. (2013). Germination studies in some varieties of J'igna unguiculata L. Walp. (Cowpea) from Northern Nigeria. Pakistan Journal of Biological Sciences, 16(20), 1220-1222. 